\title{
En busca de la poética narrativa de Juan Rulfo (oralidad y escritura en un cuento de ElUano en Vamas)
}

Françoise Perus

Instituto de Investigaciones Sociales

Universidad Nacional Autónoma de México

$\mathrm{E}$ lanálisis de uno de los cuentos de Juan Rulfo que presentamos a continuación es parte de un trabajo mayor, en curso de elaboración, acerca de la poética narrativa de El Llano en llamas. Nuestro interés por la poética narrativa de los cuentos de Rulfo parte de la constatación de que, si bien buena parte de la crítica ha destacado el profundo vínculo existerite entre la cultura popular oral y los modos de narrar de Juan Rulfo, no ha hecho el mismo hincapié en las relaciones, sin dúda conflictivas, que esta «ficcionalización de la oralidad» mantiene con diversas tradiciones escritas y «letradas.» A este respecto, llama la atención la poca reflexión que la misma crítica ha dedicado a la presencia, en varios de los cuentos de El Llano en llamas, de un. narrador en tercera persona, cuya configuración y relación con el mundo narrado es, sin embargo, harto problemática. En la presencia de este narrador, y en las profundas modificaciones que entraña respecto de las nomenclaturas al uso, pensarnos que se inscriben, no sólo la huella de las diversas tradiciones letradas de las que parte Rulfo-reelaborándolas .y transformándolas en contacto con la tradición oral y popular-sino también algunos de sus aportes más significativos a la narrativa hispanoamericana y occidental. Estos aportes--que el análisis concreto y sistemático de los cuentos debería permitir conceptualizar y traducir más adelante a términos propiamente teóricos-transforman juntos los modos de configurar el objeto de la representación 
artística y las prefiguraciones del lector implicado, y por lo tanto también la fonna en que el lector real habría de relacionarse con las propuestas narrativas y con el mundo narrado.

\section{Una forma composicional insólita}

En una primera aproximación, el relato de El Llano en llamas intitulado «El hombre» pareciera referirse a unos mismos sucesos contados desde dos perspectivas distintas. El texto consta de dos partes claramente diferenciadas entre sí mediante el uso de unas marcas específicas, tales como el punto reforzado y el blanco tipográfico. A esta disposición propiamente textual, se suma por otro lado un sorpresivo cambio de persona gramatical en la voz narrativa. La primera unidad corresponde a un narrador «externo» y en tercera persona, que intercala en la suya propia las voces interiores de quienes figuran como los protagonistas de esta primera narración: el perseguidor y el perseguido. En cambio, la segunda unidad está enunciada en primera persona y consiste en la declaración ante la autoridad judicial de quien descubrió, a la orilla del río, el cuerpo del perseguido y autor de la matanza de los Urquidi. acribillado a balazos. De modo que el cambio de persona gramatical de la voz narrativa se acompaña también de una modificación sustancial de la situación de enunciación y del contenido de la narración. Aun cuando en ambos casos los hechos aludidos o referidos sean sustancialmente los mismos-una cadena de venganzas-las diferencias de perspectiva entre sendas narraciones son tan notorias que conducen al lector a preguntarse por la unidad artística del relato.

Los hechos aludidos y la referencia en ambas unidades narrativas a un mismo personaje a quien pareciera referirse el título del relato proporcionan sin duda cierta cohesión temática al cuento. Pero dejan también sin respuesta a muchas de las interrogantes del lector ante la insólita complicación de la narración de la cadena de venganzas aludidas. y propias-al decir de algunos-de un ambiente rural, marginal o arcaico. Algunos críticos han vinculado esta complejidad narrativa a la ficcionalización y estilizaci6nde fonnas narrativas populares $\mathrm{u}$ orales provenientes de aquel ambiente. ${ }^{1}$ Sin embargo, y a pesar de que esta vinculación permite destacar algunos aspectos relevantes del cuento, deja sin resolver el papel del entrecruzamiento de perspectivas y situaciones narrativas en la composición artística de la obra, y en particular el problema que sé deriva del vínculo eventual entre los dos narradores.

Para tratar de dilucidar la índole de este vínculo y la poética narrativa que pudiera involucrar, examinaremos a continuación cada una de las narraciones por separado, tal y como se presentan al lector mediante la disposición textual especificada más arriba. En todo relato, son la configuración y las entonaciones de la voz narrativa las que guían la atención del lector, y las que orientan su 
disposición de ánimo y su capacidad valorativa respecto de los enunciados. Procuraremos dejamos guiar por ellas, atendiendo primordialmente a las formas en que, en cada una de las unidades narrativas que concurren en la composición del cuento, dicha voz se relaciona con la de quienes aparecen como los protagonistas de los sucesos relatados.

\section{La persecución}

\section{A. La voz del narrador y las de los protagonistas}

En la primera unidad narrativa, diversas marcas tipográficas permiten distinguir tres voces: la del narrador en tercera persona, sin comillas ni marca tipográfica alguna (LOS PIES del hombre se hundieron en la arena, dejando una huella sin forma, como si fuera la pezuña de algún animal); la del perseguidor, intercalada dentro de la voz del narrador mediante comillas que sugieren el carácter «pictórico» de su reproducción ("Pies planos -dijo el que lo seguía-o Y un dedo de menos. Le falta el dedo gordo'en el pie izquierdo. No abundan fulanos con estas señas. Así que será fácil."); y por último, la voz del perseguido, también entrecomillada, aunque diferenciada de la del perseguidor mediante el uso de cursivas ("Voy a lo que voy", volvió a decir. y supo que era él el que hablaba.).

Sin embargo, en la voz del perseguido, cabe distinguir entre dos tipos de enunciación: entre una voz interior-exteriorizada o no-y otra voz que se dirige momentáneamente a sus víctimas. Sólo la voz interior-antes y después de perpetrado el crimen-aparece con cursiva. Los otros enunciados dei mismo personaje-los que corresponden a la rememoración de la escena del crimen y van dirigidos a las víctimas (UDiscúlpenme", "Ustedes me han de perdonar", 38. "Discúlpenme la apuración", 42)2 carecen de cursivas. De modo que éstas sirven ante todo para distinguir entre las voces interiores del perseguidor y el perseguido, reproducidas ambas con independencia de la voz del narrador.

Con todo, también en la voz del perseguidor pueden distinguirse algunas variaciones en cuanto a su orientación, aunque dichas variaciones no se hallen tipográficamente marcadas. Inicialmente, la voz del perseguidor aparece como una voz interior que va registrando para sí las características y el comportamiento del perseguido; pero a medida que va acortándose la distancia que lo separa de su presa, el perseguidor empieza a sustituir el «él» con que venía refiriéndose al perseguido por un «tú» que, én determinado momento, se convertirá en fuente de ambiguiedad respecto de la identidad del destinatario: llega en efecto un momento en que no se sabe si el perseguidor se dirige al hijo asesinado o a quien asesinó a este último. Sobre esta ambigüedad, fundamental para la comprensión del relato de Rulfo, volveremos más adelante. Por lo pronto, queremos recalcar que mientras en la voz del perseguido se distingue claramente ( $y$ gráficamente) la palabra para sí de la palabra dirigida a otros (a las víctimas en este caso), en la dél 
perseguidor no aparece tal distinción: en su monodiálogo interior, la palabra dirigida al «otro»-víctima o victimario-no se separa nítidamente de la palabra para sí. El «tú» tiende entonces a presentarse como una prolongación del «yo,» llegando incluso a producir una momentánea confusión de identidades entre víctima y victimario.

Desde el punto de vista del paralelismo que la tipografía establece entre las voces alternadas del perseguidor y el perseguido, ello implica que la diferencia que se busca resaltar descansa en las particularidades de la voz del perseguido. Ésta es, en efecto, la que lleva la marca distintiva que permite reparar en la profunda diferencia que caracteriza a la configuración de estas voces alternas y paralelas.

Ahora bien, quien establece el paralelismo y la diferenciación entre estas voces alternadas es obviamente aquel narrador externo y en tercera persona, cuya identidad y relación con lo narrado resultan-al menos inicialmente-por demás enigmáticas. El simple apego a la convención narrativa tradiciona $1^{3}$ es a nuestro juicio insuficiente para una cabal compenetración con el mundo narrado y para la plena comprensión de la poética del relato. Esta voz externa es la que da principio a la narración, con la particularidad de que-al igual que el perseguidor, cuya palabra interna introduce casi de inmediato antes de proseguir con la descripción del terreno-el narrador también pareciera estar rastreando huellas:

LOS PIES del hombre se hundieron en la arena, dejando una huella sin forma, como si fuera la pezuña de algún animal. Treparon sobre las piedras, engarruñándose al sentir la inclinación de la subida, luego caminaron hacia arriba, buscando el horizonte.

"Pies planos -dijo el que lo seguía-o Y un dedo de menos. Le falta el dedo gordo en el pie izquierdo. No abundan fulanos con estas señas. Así que será fácil."

La vereda subía, entre yerbas, llena de espinas y de malasmujeres. Parecía un camino de hormigas de tan angosto. Subía sin rodeos hacia el cielo. Se perdía allá y luego volvía a aparecer más lejos, bajo un cielo más lejano.

Los pies siguieron la vereda, sin desviarse. El hombre caminó apoyándose en los callos de los talones, raspando las piedras con las uñas de sus pies, rasguñándose los brazos, deteniéndose con cada horizonte para medir su fin: «No el mío, sino el de él», dijo. y volvió la cabeza para ver quién había hablado. (35)

Sin embargo, aquí también la similitud entre la voz narrativa en tercera persona y la del perseguidor es sólo aparente. Además del contraste entre las maneras en que narrador y perseguidor se refieren al perseguido-«el hombre» 
en el caso del narrador, «fulano» con «señas» particulares en el del perseguidor-estas dos voces se distinguen también por sus modos de configurar el objeto común de la representación. La del perseguidor recorta y fija la imagen del perseguido en forma perentoria, reduciéndolo a la seña que lo delata y proporciona a quien lo persigue una indudable ventaja sobre su presa ("Así que será fácil".). La del narrador, en cambio, se caracteriza por ir de las huellas hacia la compenetración con el sentir y el mirar--e incluso el decir, entre resuelto y asustado-de quien las fue dejando en el terreno. . . . ("El hombre caminó apoyándose en los callos de sus talones, ( . . ) rasguñándose los brazos, deteniéndose en cada horizonte para medir su fin: "No el mío, sino el de él", dijo. y volvió la cabeza para ver quién había hablado.").

Esta diferencia fundamental de actitud y de miras entre el narrador y el perseguidor respecto de las huellas que van rastreando y, sobre todo, respecto de aquél que las fue dejando en el terreno, se halla recalcada líneas más adelante, con una nueva insercí6n de la palabra interna del perseguidor, cuyo registro escueto y reafirmación de la propia ventaja contrastan expresamente con la perspectiva adoptada a continuación por el narrador:

"Subió por aquí, rastrillando el monte -dijo el que lo perseguía-. Cortó las ramas con un machete. Se conoce que lo arrastraba el ansia. y el ansia deja huellas siempre. Eso lo perderá."

Comenzó a perder el ánimo cuando las horas se alargaron y detrás de un horizonte estaba otro y el cerro por donde subía no terminaba. Sacó el machete y cortó las ramas duras como raíces y tronchó la yerba desde la raíz. Mascó un gargajo mugroso y lo arrojó a la tierra con coraje. Se chupó los dientes y volvió a escupir. El cielo estaba tranquilo allá arriba, quieto, transluciendo sus nubes entre la silueta de los palos guajes, sin hojas. No era tiempo de hojas. Era ese tiempo seco y roñoso de espinas y de espigas secas y silvestres. Golpeaba con ansia los matojos con el machete: "Se amellará con este trabajito, más te vale dejar en paz Las cosas." (36)

Mientras que para el perseguidor el «ansia» que descubre en la calidad de las huellas vuelve a darle la seguridad de su propia victoria, para el narrador estas mismas huellas-y la «pérdida de ánimo» y el «ansia» que denotan--conducen no sólo hacia la evocación de los gestos y la disposición anímica del perseguido, sino también hacía la adopción de una forma de percepción y una mirada que tienden a fundirse con las del personaje.

De tal suerte que esta puesta en escena inicial del perseguidor y el perseguido, con sus respectivas reflexiones internas, no apunta tan sólọ a una caracterización previa de las actitudes y las disposiciones de ánimo de los personajes. Conlleva 
también una particularización del narrador, y un señalamiento de la actitud distinta que este mismo narrador mantiene con los personajes cuyas voces evoca o imagina. La particularizaci6n proviene del paralelismo inicial entre el narrador y el perseguidor, al presentarlos ambos como rastreadores de las huellas dejadas por el fugitivo en el terreno. Al respecto, no está por demás señalar que el narrador empieza comparando esas huellas «sin forma» con las de «la pezuña de algún animal.» Sin embargo, la actitud que priva en su propio rastreo se distingue de la del perseguidor, por cuanto da lugar a un esfuerzo de compenetración con la percepci6n y el estado de ánimo del «hombre,» al cual el perseguidor señala a su vez como «fulano» o como «él,» al menos antes de que adquiera la forma de un «tú,» objeto de escarnio. Salvo en el momento en que el perseguidor evoca la promesa hecha al hijo muerto, en ningún momento el narrador da muestra. de semej ante cercanía y compenetmci6n con el perseguidor, al cual designa a su vez, y sin variación alguna, simplemente como «el» ("el que lo perseguía", "el que iba detrás de él"), mientras que el término «hombre» queda reservado para el perseguido.

Por lo mismo, el narrador en tercera persona de la primera parte del relato de Rulfo no puede asimilarse simplemente a un narrador externo, que se mantuviera a igual distancia de los personajes que pone en escena, o que se aproximara o se alejara de ellos en una forma semejante. En lo que aparece claramente como una relación de poder entre ambos protagonistas, el narrador se coloca implícitamente junto al perseguido. De modo que, pese a la forma gramatical que 10 señala como narrador «externo»y abstracto, su particularización como rastreador de las huellas dejadas por el «hombre»y las perspectivas valorativas distintas que adopta respecto de quienes se hallan involucrados en la persecución y el crimen, 10 hacen aparecer como un sujeto concreto, y personalmente interesado en los sucesos evocados.

\section{B. Historia y relato 4}

A esta peculiaridad de la voz narrativa se suma el hecho insólito de que «el hombre» pareciera estar «perseguido» antes mismo de haber cometido el crimen. En efecto, esta primera parte del relato de Rulfo presenta un extraño entrevero de tiempos, en donde historia y relato no sólo no coinciden, sino que parecieran estarse contradiciendo. Si seguimos al narrador detrás de las huellas del «hombre,» podemos ver que éste sube, ansioso y machete en mano, hasta la cima en donde se encuentra la casa de sus víctimas; llega y empuja la puerta en medio de la noche cerrada; baja luego del otro lado, ya sin machete, hacia el río, guiado por la línea amarilla de los sabinos que se perfila en el amanecer de un día nublado; se adentra en el río al promediar la tarde; y por último vuelve a salir, sereno y en paz luego de un momento de alucinación, «al frío de aquella noche». 
En el marco de esta reconstitución precisa del desplazamiento espacial y temporal del perseguido por parte del narrador-quien «ve» o imagina juntos al «hombre» y su entorno físico y tiende las más de las veces a fundir su propia percepción con la de su personaje-la inserción de la voz interna de este mismo personaje contribuye a la precisión de los estados anímicos y los comportamientos descritos por el narrador: "Vaya lo que voy", "Se amellará con este trabajito, más te vale dejar en paz las cosas", "No debímatarlos a todos.... Al menos no a todos." "No debí haberme salido de la vereda ... " Etcétera.

Ahora bien, como dijimos hace un momento, estas dos voces afines y complementarias entre sí alternan con la voz interior del perseguidor, que pareciera estarle pisando los talones al «hombre,» incluso antes de que éste haya cometido su crimen. En efecto, "en el orden del relato la inserci6n de la voz del perseguidor, con su prop6sito declarado de acabar con el perseguido, contraviene el orden de los sucesos, tal y como aparecen en la reconstitución espacial y temporal de la trayectoria del «hombre» en la voz del narrador.

Esta contradicción aparente devuelve al lector al problema de la identidad del narrador, que no s610 sigue a los personajes, imagina sus pensamientos y narra la persecuci6n en tiempo pasado, conociendo de antemano su desenlace, sino que se coloca del lado del asesino y anticipa las intenciones del perseguidor, sobreponiéndolas a la reconstitución de la trayectoria física del perseguido. Pero, más que preguntarse por esta identidad relativamente enigmática-que, si no fuera por las peculiaridades antes señaladas, pudiera confundirse con la función narrativa abstracta de un narrador tradicional y extradiegético-este entrevero de tiempos lleva al lector a interrogarse acerca de la instancia misma de la narración.

\section{La instancia narrativa}

Hasta ahora, hemos podido establecer que el narrador se presenta como quien se halla siguiendo, en un terreno accidentado y enmarañado, las huellas del «hombre» que sube primero hasta el lugar del crimen y baja luego hasta el río. Hemos visto también que este narrador se adhiere a la percepci6n del fugitivo y funde a menudo su perspectiva con la de éste, cuyos estados de ánimo y pensamientos imagina a partir de las huellas que se halla rastreando. Sin embargo, otra es su actitud con el perseguidor, a quien no sigue ni representa: lo coloca ahí, con su voz y sus pensamientos internos, como una sombra que persigue o se adelanta al «hombre» a cada paso. A este respecto, no está por demás subrayar que, mientras se acerca a la .casa de sus víctimas, el «hombre» aparece en todo momento hablando en voz alta y teniendo que cerciorarse que es su propia voz a la que acaba de oír: 
( ... ) El hombre caminó apoyándose en los callos de sus talones, ( ... ) deteniéndose en cada horizonte para medir su fin: "No el mío, sino el de él", dijo. y volvió la cabeza para ver quién había hablado. (35)

( . . . ) Desvanecido a fuerza de ir a tientas, calculando sus pasos, aguantando la respiración: "Voy a lo que voy", volvió a decir. Y supo que era él el que hablaba. (35-36)

( ... ) Golpeaba con ansia los matojos con el machete: "Se amellará con este trabajito, más te vale dejar en paz las cosas:"

Oyó allá atrás su propia voz. (36)

Estas acotaciones del narrador tienen sin duda por objeto dar cuenta del miedo que embarga a quien se dispone a matar. Con todo, dejan suponer la presencia del eco de otra voz en la conciencia del futuro asesino. Esta otra yoz, presente aunque silenciada por el personaje. podría ser entonces aquella a la cual el narrador se encarga de dar forma con la inserción de las palabras internas del perseguidor. Éstas, no obstante, no corresponden siempre al momento cronológico de la trayectoria del fugitivo. Casi desde el inicio del relato parecieran anticiparse a la matanza que supuestamente las justifican, e incluso a la muerte del perseguido, que sólo aparece confirmada con la declaración posterior del borreguero, en la segunda unidad narrativa:

Oyó allá atrás su propia voz.

"Lo señaló su propio coraje - dijo el perseguidor-o Él ha dicho quién es, ahora sólo falta saber dónde está. Terminaré de subir por donde subió, después bajaré por donde bajó, rastreándolo hasta cansarlo. Y donde yo me detenga, allí estará. Se arrodillará y me pedirá perdón. y yo le dejaré ir un balazo en la nuca ... Eso sucederá cuando yo te encuentre."

Llegó al final. 5610 el puro cielo, cenizo. medio quemado por la nublazón de la noche.

( ... ) Entonces empujó la puerta sólo cerrada a la noche. (36-37)

Es de suponer entonces que los pensamientos internos que el narrador atribuye al perseguidor parten del conocimiento del desenlace de la persecución en tomo a la cual se organiza el relato. Puede asegurarse incluso que es partir de este conocimiento que reconstruye a aquélla, siguiendo las huellas dejadas por el «hombre,» e imaginando a éste en su condición de perseguido, antes y después de haber cometido lo que, con las declaraciones del borreguero ante la autoridad judicial en la segunda parte del relato, aparecerá como la matanza de los Urquídi. La superposición de la voz interior del perseguidor a la trayectoria y los pensa- 
mientas del fugitivo dejan suponer entonces que el relato del narrador consiste en una reconstitución, interior e imaginada, de la persecución a partir de su desenlace. y siguiendo la trayectoria y las huellas dejadas por el «hombre» en el terreno. Algunas marcas de oralidad en el estilo del narrador podrían confirmar la hipótesis de que estamos ante una forma de monólogo interior ${ }^{5}$ que, contrariamente a las leyes acostumbradas del género, no se aboca al desentrañamiento de la propia subjetividad, sino a la persecución de alguna verdad recóndita, encerrada en la sucesión de crímenes que involucran tanto al «hombre» como al «perseguidor.»

\section{En pos de la verdad recóndita}

La búsqueda de esta verdad recóndita, que refuerza a su vez la oposición entre los objetivos del narrador y los del perseguidor, permite entender otras características de la configuración de la voz de este último. En efecto, mientras la del «hombre," y los contenidos subjetivos que pone de manifiesto, siguen el orden cronológico de los sucesos (el miedo y el ansia antes de cometer el crimen, la huida y el remordimiento por la matazón injusta, y el extravío y la paralización junto al río por el peso de la culpa), las orientaciones de la voz del perseguidor se caracterizan por la interferencia de dos movimientos contrarios. El primero de estos movimientos concierne al rastreo de las huellas y a la persecución propiamente dicha, con la particularidad de que el seguimiento inicial se troca subrepticiamente en adelanto y espera de la víctima. El segundo movimiento consiste a su vez en un inesperado remontarse hasta los orígenes de la cadena de venganzas implicadas en la situación actual. Propiciado por la inmovilidad de la espera, y enlazado con el movimiento anterior por el trastrocamiento del sentido y la orientación de la persecución-que coincide por otra parte con el extravío y la paralización del perseguido junto al río-Ia aparición de este segundo movimiento da lugar a su vez a la transformación del «él, » con que el perseguidor venía designando al fugitivo, en un «tú» algo enigmático.

Antes de examinar la forma en que el perseguidor evoca los orígenes de la doble venganza, conviene reparar en las modificaciones concomitantes de la focalización del narrador. A medida que va acercándose al momento de la confrontación imaginaria entre los protagonistas y alargándose los parlamentos interiores de ambos, su visión del entorno físico se separa de la del perseguido para adquirir una dimensión ostensiblemente metafórica. Hemos registrado en su momento la compenetraci6n de la voz del narrador con la percepción del perseguido antes del crimen: "Comenzó a perder el ánimo cuando las horas se alargaron ... " (36). Esta misma forma de compenetración se mantiene, con algunas interferencias entre las visiones internas y externas, hasta la llegada del hombre a las orillas del río: 
El hombre bajó buscando el río, abriendo una nueva brechaen el monte.

Muy abajo el río corre mullendo sus aguas entre sabinos florecidos, meciendo su espesa corriente en silencio. Carnina y da vueltas sobre sí mismo. Va y viene corno una serpentina enroscada sobre la tierra verde. No hace ruido. Uno podría donnir allí, junto a él, y alguien oiría la respiración de uno, pero no la del río. La yedra baja desde los altos sabinos y se hunde en el agua, junta sus manos y forma telarañas que. el río no deshace en ningún tiempo.

El hombre encontró la línea del río por el color amarillo de los sabinos. - No lo oía. Sólo lo veía retorcerse bajo las sombras. Vio venir las chachalacas. La tarde anterior se habían ido siguiendo el sol, volando en parvadas detrás de la luz. Ahora el sol estaba por salir y ellas regresaban de nuevo.

Se persignó hasta tres veces. "Discúlpenme", les dijo. y comenzó su tarea.... (37-38)

El sorpresivo cambio de tiempo verbal en el segundo párrafo de esta cita, es decir el uso repentino de un presente descriptivo, indica que la percepción del narrador coincide ahora con el presente de la enunciación, y ya no con el tiempo pasado de la narración. Por lo mismo, introduce una distancia, antes inexistente, respecto de la percepción del fugitivo. Al retornar luego la narración, el narrador vuelve momentáneamente a acercarse a la percepción del perseguido, aunque sin confundirse plenamente con ella ("No lo oía. Sólo lo veía retorcerse bajo las sombras. Vio venir las chachalacas."). A su vez, la reflexión inmediatamente posterior ("La tarde anterior se habían ido siguiendo al sol, volando en parvadas detrás de la luz.") parece reintroducir la perspectiva del presente de la enunciación, al referirse a una «tarde anteriorł cuya ubicación cronológica toma por referencia la llegada del personaje junto al río. Con todo, pudiera haber cierta ambigüedad en esta precisión temporal, lo mismo que en la inserción, un poco más adelante, de una nueva mención del paso de las chachalacas en medio de las reflexiones interiores del perseguido:

"Éste no es el lugar - -dijo el hombre al ver el río-. Lo cruzaré aquíy luego más allá y quizá salga a la misma orilla. Tengo que estar al otro lado, donde no me conocen, donde nunca he estado ynadie sabe de mi; luego caminaré derecho, hasta llegar. De allínadie me sacará nunca." Pasaron más parvadas de chachalacas, graznando con gritos que ensordecían.

"Caminaré más abajo. Aquíel, io se hace un enredijo y puede devolvenne a donde no quiero regresar." (39) 
En este caso, el registro del paso de la bandada de pájaros parece corresponder al narrador, aunque tampoco puede descartarse una oposición entre la voz interna y el registro del entorno por parte del personaje. Sin embargo, la ambigüedad desaparece por completo en la siguiente intervención del narrador, que rompe con la larga alternancia de las dos voces del perseguidor y el perseguido:

El hombre vio que el río se encajonaba entre altas paredes y se detuvo. "Tendré que regresar", dijo.

El río en estos lugares es ancho y hondo y no tropieza con ninguna piedra. Se resbala en un cauce como de aceite espeso y sucio. Y de vez en cuando se traga alguna rama en sus remolinos, sorbiéndola sin que se oiga ningún quejido. $(41-42)$

Ahora bien, pese a la distancia introducida por el presente de la enunciación, tanto las imágenes del río como las del paso de las chachalacas, buscando la luz y graznando con gritos ensordecedores, guardan estrecha relación con los movimientos físicos y anímicos del perseguido. Tejen una red de imágenes que confiere al río, a la luz y a las sombras, y al paso de las aves un valor eminentemente metafórico. Así, la primera descripción del río como callada serpentina se asocia con otra imagen anterior y casi contigua: la del machete que, después de matar, el fugitivo abandona al alba, en medio del camino:

La madrugada estaba gris, llena de aire frío. Bajó hacia el otro lado, resbalándose por el zacatal. Soltó el machete que llevaba todavía apretado en la mano cuando el frío le entumeció las manos. Lo dejó allí. Lo vio brillar como un pedazo de culebra sin vida, entre las espigas secas.

El hombre bajó buscando el río, abriendo una nueva brecha entre el monte.

Muy abajo el río corre muliendo sus aguas entre sabinos florecidos; meciendo su espesa corriente en silencio. Camina y da vueltas sobre sí mismo. Va y viene como una serpentina enroscada sobre la tierra verde. (37)

La asociación entre el machete-pedazo de culebra sin vida-y el río enroscándose sobre la tierra verde subraya las ambigüedades de este río: su asociación con la vida, por un lado, mediánte la relación con el movimiento, los sabinos en flor y la tierra verde; y su recóndito vínculo con la muerte, por el otro, mediante la evocación indirecta del machete mortífero por asociación con la serpentina enroscada, las vueltas sobre sí mismo, y la profundidad del silencio. El vuelo de las chachalacas, yendo y viniendo en busca de la luz, pero anunciando también la proximidad de la muerte con sus gritos ensordecedores, refuerzan la ambigüedad de esta atmósfera, en donde la vida se halla en pugna con la muerte. La . 
metaforización de las imágenes asociadas al río permite entonces al narrador insinuar el desenlace de esta primera parte del relato:

El hombre vio que el río se encajonaba entre altas paredes y se detuvo. "Tendré que regresar", dijo.

El río en estos lugares es ancho y hondo y,no tropieza con ninguna piedra. Se resbala en un cauce de aceite espeso y sucio. Y de vez en cuando se traga alguna rama en sus remolinos, sorbiéndola sin que se oiga ningún quejido. (41-42)

En la última parte de nuestro análisis, volveremos sobre esta visión, a la vez externa y metafórica, del entorno por parte del narrador. Por ahora quisiéramos retomar el problema planteado por los dos movimientos encontrados de la voz del perseguidor. Hemos evocado en su momento la inmovilidad del perseguidor a la espera de su víctima acorralada, y hemos señalado también el desplazamiento del «él» al «tú » para referirse al perseguido. Al principio de este estudio, hemos recalcado asimismo que la percepción inicial que el perseguidor tiene del sujeto al cual viene rastreando' tiende a limitarse a la proyección de su propia obnu. bilación por el afán de venganza. Adelantamos incluso que esta obnubilación-que impide distinguir entre el yo y el otro-habría de conducir más adelante a una confusión momentánea acerca de la identidad de la víctima y el victimario.

En efecto, en el entrevero de las voces del perseguido y el perseguidor, y enseguida de la mención que hiciera mentalmente el primero de que «Aquí el río se hace un enredijo y puede devolverme a donde no quiero regresar,» vuelve a surgir la voz del perseguidor con el siguiente encadenamiento, puntuado por algunas reflexiones del narrador:

"Nadie te hará daño nunca, hijo. Estoy aquí para protegerte. Por eso nací antes que tú y mis huesos se endurecieron primero que los tuyos." Oía su voz, su propia voz, saliendo despacio de su boca. La sentía sonar como una cosa falsa y sin sentido.

¿Por qué habría dicho aquello? Ahora su hijo se estaría burlando de él. O tal vez no. "Tal vez esté lleno de rencor conmigo por haberlo dejado solo en nuestra última hora. Porque era también la mía; era únicamente . la mía. Él vino por mí. No los buscaba a ustedes, simplemente era yo el final de su viaje, la cara que él soñaba ver muerta, restregada contra el lodo, pateada y pisoteada hasta la desfiguración. Igual que lo que yo hice con su hermano, pero yo lo hice cara a cara, José Alcancía,frente a él y frente a ti y tú nomás llorabas y temblabas de miedo. Desde entonces supe quién eras y cómo vendrías a buscarme. Te esperé un 
mes, despierto de día y de noche, sabiendo que llegarías a rastras, escondido como una mala víbora. y llegaste tarde. Y yo también llegué tarde. Llegué detrás de ti. Me entretuvo el entierro del recién nacido. Ahora entiendo. Ahora entiendo por qué se me marchitaron las flores en las manos." (40) El subrayado es mío.

Varios tiempos y varios sucesos se entremezclan en la evocaci6n del origen de esta cadena de venganzas. El primer tiempo es, desde luego, el presente de la enunciaci6n y la espera. El segundo, pasado y remoto, aunque indefinido, corresponde a la evocación de la promesa hecha al hijo, ahora muerto. Pasada la intervenci6n del narrador, que subraya la falsedad y el sinsentido con que resuenan sus propias palabras en el oído del perseguidor, surge brevemente el momento de la matanza de la que escapó el perseguidor, mas no el hijo, objeto de la promesa anterior. De ahí, acaso, el sinsentido del recuerdo, la falsedad de la voz, y el temor a la burla o al rencor del hijo (muerto). La breve evocación de la escena del crimen, donde el hijo muere en lugar del padre, desencadena a su vez el recuerdo de otra escena anterior, en la cual el que recuerda y figura ahora como «el perseguidor' mata con saña, y en presencia de quien figura a su vez como «el perseguido,» al hermano de este último. Viene luego la evocación del tiempo en que el padre y asesino espera el regreso de quien presenció, atemorizado por el miedo, la muerte de su hermano, con el prop6sito de vengarlo. Y, por último, surgen las circunstancias que propiciaron el descuido y la ausencia del padre en el momento de la venganza y, por consiguiente, la falta de cumplimiento de la palabra empeñada ante el hijo: el entierro de otro hijo, muerto recién nacido, en vísperas del crimen.

Ahora bien, en el entrevero de tiempos de esta sucesión de reminiscencias. llama la atención una extraña confusi6n-o sustitución-de las identidades a las que se refieren el «éll» y el «tú»», en particular en el momento de la evocación de la muerte del hermano del perseguido a manos del ahora perseguidor:

( ... ) Él vino por mí. No los buscaba a ustedes, simplemente era yo el final de su viaje, la cara que él soñaba ver muerta, restregada contra el lodo, pateada y pisoteada hasta la desfiguración. Igual que lo que hice con su hermano; pero lo hice cara a cara, losé Alcancía, frente a él y frente a ti y tú nomás lIoiabas y temblabas de miedo. Desde entonces supe quién eras y cómo vendrías a buscarme. (40)

Esta confusión de identidades entre el «él» yel «tú» en el momento de mayor violencia deja entrever la posibilidad de que las tres personas implicadas ahí-si es que son tres--eran muy probablemente tres hermanos (de padre al menos, ya que tampoco resulta muy claro a quién se refiere el nombre de José Alcancía). La 
familiaridad con que los perros reciben al asesino en la noche cerrada del crimen ("Toc61 a puerta sin querer, con el mango del machete. Un perro llegó y le lamió las rodillas, otro más corrió a su alrededor moviendo la cola." (37) y el hecho de que el perseguidor conociera de tan cerca las señas del perseguido ("Pies planos -dijo el que lo seguía-o y un dedo de menos. Le falta el dedo gordo en el pie izquierdo. No abundan los fulanos con estas señas. Así que será .fácil." (35) refuerzan esta hipótesis: dejan suponer una estrecha convivencia anterior entre el perseguidor y el perseguido.

En cuanto a la confusi6n de identidades, vuelve a insinuarse más adelante, poco antes del desenlace de esta primera unidad narrativa:

"Hijo -dijo el que estaba sentado esperando--: no tiene caso que te diga que el que te mató está muerto desde ahora. ¿Acaso yo ganaré algo con eso? La cosa es que yo no estuve contigo. ¿De qué sirve explicar nada? No estaba contigo. Eso es todo. Ni con ella Ni con él. No estaba con nadie; porque el recién nacido no me dejó ninguna señal de recuerdo." (42)

En este nuevo diálogo imaginario con el hijo muerto, aparece varias veces el «él»: designa primero al perseguido (el que te mató); luego, en la enumeración que sigue (Uno estuve contigo.... Eso es todo. Ni con ella. Ni con él.."), sorprende la aparición de este pronombre, porcuanto el antecedente inmediato no podría ser sino, y nuevamente, el perseguido, lo cual no deja de plantear cierta contradicción, salvo que el perseguido sea efectivamente hijo del perseguidor. Sin embargo, el desarrollo posterior de la reflexión ("No estaba con nadie; porque el recién nacido no me dejó ninguna señal de recuerdo.") parece referir, retrospectivamente, este «él» al recién nacido. De modo que si establecemos un paralelo entre los dos momentos de la reflexión interna del perseguidor en paralelo, el pronombre «éll» aparece como la manera que tiene el padre y perseguidor de designar sucesiva e indistintamente a sus hijos no predilectos (el perseguido y su hermano, primero, y el recién nacido, luego). Por otra parte, no está por demás subrayar que este mismo pronombre es el que usan el perseguido y el narrador para referirse al padre y perseguidor.

La arbitrariedad, la violencia física y emocional hacia el otro, y la soledad más profunda son, así pues, los rasgos que dejan aflorar estas reminiscéncias y reflexiones del personaje. Sin embargo, ni la asunción de esta verdad recóndita, ni el reconocimiento íntimo de lo vano de la venganzapr6xima, son suficientes para detener el brazo mortífero. La verdad íntima se troca en indiferencia, al parecer por la imposibilidad de renunciar a la imagen cristalizada de sí mismo--e indefectiblemente identificada con el poder absoluto--que la falta de cumpli. miento de la palabra empeñada ante el hijo predilecto puso en entredicho. Resalta, 
como contraparte, el remordimiento y el sentimiento de culpa que, mientras tanto, inmovilizan al perseguido en los caños entreverados del río, y lo hacen salir finalmente, sereno y en paz después de algún arranque de burla socarrona ("Después de todo, así de a muchos les costará menos el entierro", (39) al encuentro de la muerte.

Esta primera parte' de la narración de Rulfo podría ser en sí misma un cuento, cuya poética narrativa resulta bastante similar a la de «Luvina.» Un narrador externo y en tercera persona va detrás de unos personajes, imaginando sus voces interiores y el diálogo implícito entre ellos sin que sus respectivas voces lleguen jamás a encontrarse, y persiguiendo la verdad íntima que los atormenta e inhibe el encuentro entre ambos. Como en «Luvina,» esta voz narrativa tiende a fundirse con la percepción de Jos personajes, pero se aleja también en Jos momentos más álgidos del ensimismamiento o de la confrontación ciega, para restablecer una percepción menos sombría del entorno y contrastar la obnubilación del personaje con los signos de vida que éste ha dejado de percibir. En otras palabras, si bien este narrador busca compenetrarse con sus personajes, seguir los meandros de sus pensamientos más recónditos y alcanzar su verdad íntima, no comparte su dimensión agónica, y llama al lector a distanciarse también de ésta y a volver a mirar el mundo con otros ojos. ${ }^{6}$

\section{II. La declaración del borreguero}

Ahora bien, el relato de Rulfo no termina con esta primera narración, sino que a ésta le yuxtapone una segunda, que retoma la historia contada desde otra perspectiva: la de la declaración del borreguero ante la autoridad judicial. Pero esta declaración-en forma de monodiálogo, por cuanto que la voz de la autoridad no se oye sino en las respuestas del borreguero--es también y ante todo una autodefensa ante la acusación implícita de encubrimiento o de complicidad con del autor de la matanza de los Urquidi. De ahíla argumentación zigzagueante del declarante: al defenderse y justificarse, éste finge la adopción del punto de vista de la autoridad judicial-para la cual no hay más crimen que el de los Urquidi-hace protestas de su ignorancia de borreguero. y filtra al mismo tiempo una serie de datos que complementan el relato anterior. Así es cómo nos enteramos del vínculo que se estableció entre el borreguero y el «hombre» al llegar éste a las orillas del río; vínculo que es precisamenté el que el borreguero trata a la vez de sostener y desvirtuar ante las acusaciones que pareciera estarle formulando el «licenciado,»

\section{A. Contigüidad de los monólogos: el narrador de la primera parte y el borreguero}

Hasta ahora, esperamos haber logrado mostrar que la narración de la primera parte consiste en una suerte de monólogo interior, que parte del descubrimiento del 
cuerpo acribillado del «hombre» a la orilla del río e imagina la persecuci6n de la que este mismo «hombre» era objeto, siguiendo sus huellas en el terreno. Esta reconstituci6n imaginaria está orientada por la búsqueda de la verdad rec6ndíta subyacente en el duelo a muerte entre el perseguidor y al perseguido, y parece corresponder a un narrador particularizado, cuya perspectiva se muestra afín a la del «hombre» muerto. Ahora bien. dadas las caractérísticas de la declaración del borreguero, podemos suponer que éste no es, a fin de cuentas, sino el sujeto de la narración imaginaria de la primera parte. Más aún, podemos deducir que este primer monólogo interior y la posterior declaración-voluntaria-del borreguero ante la autoridad judicial parten de un mismo hecho, o de una misma «imagen»: el descubrimiento del cuerpo del «hombre» acribillado a balazos ("Yo s610 vengo a decirle que allí en un charco,del río está un difunto." 46).

\section{B. Una nueva forma de persecución}

Quedaría sin embargo por explicar el carácter zigzagueante de la declaración del borreguero. En la cadena de venganzas aludidas, todo parece indicar que «el crimen» que se ha de castigar no es exactamente el mismo para el borreguero que para la autoridad judicial. En efecto, para ésta no hay más crimen que la matanza de «la familia de los Urquidi, » mientras que para el borreguero el objeto primordial de su declaración consiste en el descubrimiento del cuerpo del «hombre,» baleado a mansalva y por la espalda. De ahí que su exposición inicial consista en relatar su propio encuentro con el ahora occiso, en recalcar la traza de perseguido y desamparado de aquél, y en dar cuenta de su propia perplejidad:

Parecía venir huyendo.... Lo vi que temblaba de frío....

Vi que no traía machete ni ninguna arma. Sólo la pura funda que le colgaba de la cintura, huérfana.

Miró y remir6 para todos lados y se fue. y ya iba yo a enderezanne para arriar mis borregos, cuando lo vi volver con la misma traza de desorientado'.

Se metió otra vez al río, en el brazo de en medio, de regreso.

"¿Qué trairá este hombre?", me pregunté.

y nada. Se echó de vuelta al río ... (42-43)

Ahora bien, esta exposición inicial deja suponer también la sobreposición de cierto conocimiento del «hombre,» o de cierto trato con él, por la menci6n de la «orfandad.» Aunque ésta se refiere expresamente a la funda del machete, caracteriza también la traza del «hombre» y la percepción que de éste tenía el borreguero; percepción a la que se aferra a todo lo largo de su declaración, pese a los comentarios tajantes y defensivos que responden a las aseveraciones o a las acusaciones del «licenciado.» En efecto, no dejan de sorprender la versatilidad 
cuerpo acribillado del «hombre» a la orilla del río e imagina la persecución de la que este mismo «hombre» era objeto, siguiendo sus huellas en el terreno. Esta reconstitución imaginaria está orientada por la búsqueda de la verdad recóndita subyacente en el duelo a muerte entre el perseguidor y al perseguido, y parece corresponder a un narrador particularizado, cuya perspectiva se muestra afín a la del «hombre» muerto. Ahora bien, dadas las características de la declaración del borreguero, podemos suponer que éste no es, a fin de cuentas, sino el sujeto de la narración imaginaria de la primera parte. Más aún, podemos deducir que este primer monólogo interior y la posterior declaración-voluntaria-del borreguero ante la autoridad judicial parten de un mismo hecho, o de una misma «imagen»: el descubrimiento del cuerpo del «hombre» acribillado a balazos ("Yo s610 vengo a decirle que allí en un charco del río está un difunto." 46).

\section{B. Una nueva forma de persecución}

Quedaría sin embargo por explicar el carácter zigzagueante de la declaración del borreguero. En la cadena de venganzas aludidas, todo parece indicar que «el crimen» que se ha de castigar no es exactamente el mismo para el borreguero que para la autoridad judicial. En efecto, para ésta no hay más crimen que la matanza de «la familia de los Urquidi,» mientras que para el borreguero el objeto primordial de su declaración consiste en el descubrimiento del cuerpo del «hombre,» baleado a mansalva y por la ẹppalda. De ahí que su exposici6n inicial consista en relatar su propio encuentro con el ahora occiso, en recalcar la traza de perseguido y desamparado de aquél, y en dar cuenta de su propia perplejidad:

Parecía venir huyendo.... Lo vi que temblaba de frío....

Vi que no traía machete ni ninguna arma. Sólo la pura funda que le colgaba de la cintura, huérfana.

Miró y remiró para todos lados y se fue. Y ya iba yo a enderezarme para arriar mis borregos, cuando lo vi volver con la misma traza de desorientado.

Se meti6 otra vez al río, en el brazo de en medio, de regreso.

"¿Qué trairá este hombre?", me pregunté.

Y nada. Se echó de vuelta al río ... (42-43)

Ahora bien, esta exposición inicial deja suponer también la sóbreposición de cierto conocimiento del «hombre,» o de cierto trato con él, por la mención de la «orfandad.» Aunque ésta se refiere expresamente a la funda del machete, caracteriza también la traza del «hombres y la percepci6n que de éste tenía el borreguero; percepci6n a la que se aferra a todo lo largo de su declaraci6n, pese a los comentarios tajantes y defensivos que responden a las aseveraciones $\mathrm{o}$ a las acusaciones del «licenciado.» En efecto, no dejan de sorprender la versatilidad 
de sus apreciaciones, según su relato se orienta hacia la percepción del «hombre» y el recuerdo del trato entablado entre ambos, o según responde a las palabras (¿las amenazas?) de la autoridad judicial:

¿Dice usted que mató a toditita la familía de Los Urquidi? De haberlo sabido lo atajo a puros leñazos,

Pero uno es ignorante. Uno vive remontado en el cerro, sin más trato que los borregos, y los borregos no saben de chismes,

y al otro día se volvió a aparecer. Al llegar yo, llegó él. y hasta entramos en amistad.

Me contó que no era de por aquí, que era de un lugar muy lejos; pero que no podía andar ya porque le fallaban las piernas. «Camino y camino y no ando nada, Se me doblan las piernas de la debilidad. y mi tierra está lejos, más allá de aquellos cerros.» Me contó que se había parado dos días sin comer más que puros yerbajos. Eso me dijo,

¿Dice usted que ni piedad le entró cuando mató a los familiares de los Urquidi? De haberlo sabido se habría quedado en juicio y con la boca abierta mientras estaba bebiéndose la leche de mis borregas.

Pero no parecía malo. Me contaba de su mujer y de sus chamacos, y de lo lejos que estaban de él. Se sorbía los mocos al acordarse de ellos. y estaba reflaco, como trasijado.... (45)

\section{El doble desenlace}

En el transcurso del diálogo entre el declarante y su interlocutor, esta versatilidad tiene sin embargo algunos matices y se transforma paulatinamente en una notable firmeza por parte del borreguero. Pese a sus aparentes concesiones al punto de vista de la ley-llevadas hasta una exageración casi grotesca y por lo mismo sospechosa ("pero se ha de sentir sabroso ayudarle a Dios a acabar con esos hijos del mal»)-el borreguero no ceja en su empeño de retratar al «hombre» como afligido, desamparado y hambriento, contestando así, de modo indirecto, a cada una de las aseveraciones del «licenciado» mediante una nueva anécdota:

"El animalito murió de enfermedad", le dije yo.

Pero como sí no me oyera. Se lo tragó enterito. Tenía hambre.

Pero dice usted que acabó con la vida de esa gente, De haberlo sabido. Lo que es ser ignorante y confiado. y o no soy más que borreguero y de ahí en más no sé nada. iCon decirle que se comía mis mismas tortillas y que las embarraba en mi mismo plato! (46)

Este empeño en sostener la misma percepción y evaluación del «hombre,» pese al cúmulo de acusaciones que en contra de éste formula el «licenciado,»se 
ampara por otra parte en la supuesta y reiterada ignorancia del borreguero y sus borregos «que no saben de chismes.» El personaje finge así su adhesión a la imagen estereotipada que de la gente de su condición tienen otros sectores sociales, y en particular quien aparece aquí revestido de la autoridad judicial. y si decimos «finge,» es por cuanto el monólogo de ·la primera parte muestra precisamente que el borreguero es todo menos «ignorante» y «confiado:» su suspicacia y sus cavilaciones, y no s610 la fraternidad que en otro momento fue estableciéndose entre los dos hombres, lo condujeron entonces a la formulación de una «verdad posible,» bastante distinta de la «verdad» prefabricada e inconmovible que, desde su posición de poder-y la confusión de éste con el de los Urquidi-se empeña en asestar el «licenciado.»

La «ignorancia» detrás de la cual se ampara el borreguero, y la testarudez que pareciera estarla acompañando, son entonces las que permiten al declarante sostener su punto de vista sobre el occiso. Pero son también y sobre todo las que le van a permitir colocar al «licenciado» ante la obligación moral-de una averiguación bastante distinta de la que tenía entre manos:

y ahora se ha muerto. Yo creí que había puesto a secar sus trapos entre las piedras del río; pero era él, enterito, el que estaba allí boca abajo, con la cara metida en el agua. Primero creí que se había doblado al empinarse sobre el río y no había podido enderezar ya la cabeza y que luego se había puesto a resollar agua, hasta que le vi la sangre coagulada que le salía por la boca y la nuca repleta de agujeros como si lo hubieran taladrado.

Yo no voy a averiguar eso. S610 vengo a decirle lo que pasó, sin quitar ni poner nada. Soy borreguero y no sé de otras cosas. (47) El subrayado es mío.

Por lo demás, con este desenlace magistral, no son sólo la entereza y la habilidad del borreguero frente a la venalidad de la autoridad judicial, las que salen a relucir. Son también la cobardía y la bajeza de ánimo de quien, pese a sus alardes de dominador, mató a mansalva y por la espalda; a un hombre- $¿$ a su propio hijo?---desarmado, acorralado y arrepentido.

\section{La poética del cuento}

De todos los cuentos de El Llano en llamas, «El hombre» es probablemente uno de los más complejos, por lo insólito de su composición. Desconcíertade entrada su extraña bipartición en dos unidades narrati vas distintas; y más aún el hecho de que, pese a referirse a un mismo asunto, estas unidades correspondan a narradores formalmente diferenciados, tanto por el cambio de persona gramatical como por la situación, la forma y el tono de la enunciación. Despejado el análisis de cada 
una de estas unidades, quisiéramos volver ahora sobre el problema de su unidad artística, introduciendo algunas consideraciones de orden más general.

\section{A. Oralidad y escritura}

La primera de estas consideraciones concierne a la relaci6n entre oralidad y escritura. Si como pensamos, el cuento en tanto que género contiene en sí mismo la memoria de su origen oral, ${ }^{7}$ no cabe duda de que, por su extensión, su forma de composición, su tono y estilo, cada una de las unidades que componen el cuento de Rulfo evoca esta memoria oraL Ambas' son monólogos--o mejor dicho monodiálogos ${ }^{8}$-relativamente cortos, en 'donde la alternancia de voces confiere a la narración una indudable resonancia auditiva, subrayada en ambos casos, aunque de muy distinta manera, por la particularización del sujeto y la situación de enunciación.

Esta particularización nos ha permitido identificar al narrador en tercera persona de la primera parte como el borreguero, cuya declaración ante la autoridad judicial oímos luego en la segunda parte. y es también la que nos ha llevado a considerar al primer relato como una suerte de mon6logo interior, en donde el mismo borreguero imagina la voz interior y la trayectoria externa e interna de los' personajes cuyas huellas encontró en el terreno (el cuerpo acribillado primero, y las huellas de los pies del «hombre,» más tarde). Con su alternancia de voces, este monólogo, más imaginativo que propiamente «interior,» comparte por lo demás ciertos rasgos con las formas populares de referir acontecimientos en los cuales-como también es costumbre en este tipo de relatos-se halla involucrada más de una persona. Desde este punto de vista, podemos reconocer en la primera unidad narrativa la huella de los cuenteros pueblerinos, de cuyo arte aprendió sin duda el narrador jalisciense; en particular aquél que consiste en poner a actuar y hablar a los personajes y a seguirlos en pos de una posible verdad recóndita, que en todo caso habrá de sugerirse y no afirinarse en fonna perentoria. ${ }^{9}$

En la segunda parte del relato, las marcas de oralidad provienen ante todo de la situaci6n de enunciación y de la presencia implícita del interlocutor, Pero pueden rastrearse también en el tono y el acento del declarante, destinados a reforzar el estereotipo de la «ignorancia» y la «credulidad» supuestas de las que se vale el borreguero para llevar al «licenciado» a su propio terreno. Esta fingida adhesi,6n de quien se halla en una situación de subordinación social a la imagen prejuiciada que de él tiene un interlocutor más poderoso constituye sin duda otra forma de apelación a formas de comportamiento discursivo ancladas en la cultura popular oral.

Ahora bien, no saltan a la vista el vínculo entre los dos monodiálogos que componen el cuento, y el humor específicamente rulfiano que se desprende de su yuxtaposición y engarce final. Tan es asíque no han sido destacados por lacríticá, 
al menos hasta donde sepamos. Ambos suponen un examen detenido de las marcas, incluso tipográficas, de un texto esencialmente escrito, cuya memoria cultural oral no se recobra sino hasta después de varias lecturas. Ello se debe en parte al hecho de que el lenguaje del narrador de la primera unidad no lleva ninguna marca estilística particular. Su tono y su estilo deliberadamente «neutros» inducen más bien a confundirlo inicialmente con la figura de un narrador externo, que configura las voces y las acciones de los personajes desde fuera, y manteniéndose a distancia del asunto narrado. De hecho, la identidad de este narrador y, junto con ésta, las circunstancias, la perspectiva y la fonna imaginada de su monodiálogo, no se revelan plenamente sino hasta la declaración del borreguero ante la autoridad judicial.

Como los de los cuenteros pueblerinos, los cuentos de Rulfo están llenos de pistas falsas. A cada paso, el lector tiene que descartar y desandar los caminos trillados, ajustando su percepción y su valoración a la de un narrador que 10 invita a convertirse, él también, en un rastreador de huellas inciertas, y por consiguiente a modificar constantemente la distancia y la perspectiva que lo separan de los personajes y de los sucesos evocados. Para ello, no dispone obviamente más que de las marcas textuales, la disposición y las señales tipográficas incluidas. Sin embargo, y a diferencia de lo que sucede en el relato oral acompañado de gesto y mímica, puede también volver atrás en busca de los signos en los que no había reparado inicialmente, y reorientar su compenetración con las situaciones y las perspectivas narrativas. En otras palabras, sólo después de varias lecturas detenidas puede el lector rescatar plenamente la dimensión «oral» del relato rulfiano, releer a éste oyéndolo, y sacar otras y nuevas consecuencias para su compenetración con el mundo narrado.

\section{B. $\ll \mathbf{E} \mathbf{I}$ hombre» y los hombres}

En esta misma perspectiva, quisiéramos volver ahora sobre el título del cuento. A primera vista, y dada la repetición inmediata del título en la primera frase con que principia el relato, el «hombre» no pareciera designar aquí más que al perseguido. Hemos visto incluso que dicha palabrajamás se emplea para designar al perseguidor, uniformemente señalado como «êl,» pronombre éste que, por cierto, sirve también al perseguidor no sólo para designar al perseguido, sino también para mencionar y confundir a sus hijos no predilectos. En la segunda parte del cuento, la palabra «hombre» reaparece en boca del borreguero-"¿Qué trairá este hombre?", me pregunté (43)-para designar a quien el «licenciado» parecíera a su vez no poder concebir sino como un asesino desalmado: ¿¿Dice usted que ni piedad le entró cuando mató a los familiares de los Urquidi?" (45).

Dada la compenetración del narrador de la primera parte con la percepcíón y el estado anímico del perseguido-y no así con los del perseguidor-podemos 
colegir entonces que, además de designar al perseguido y luego occiso, el uso de la palabra «hombre» conlleva el señalamiento de una perspectiva valorativa, consustancial a la vez a la figura del narrador y a la persona del borreguero. A la luz de las dos unidades narrativas yuxtapuestas, esta perspectiva valorativa aparece afianzada en la fraternidad entre el perseguido y el borreguero, ambos explícitamente señalados como subalternos dentro de una estructura social basada en la desigualdad, y colocados en la situación de perseguido por las arbitrariedades de los detentares del poder (llámese padre, Urquidi, o representante de la ley). Reafirmada por la postura a la vez firme y astuta del borreguero ante la autoridad judicial, esta perspectiva valorativa es la que propicia el desenlace del cuento y la insidiosa puesta en tela de juicio del comportamiento de dicha autoridad y su colusión con el poder.

Ahora bien, las dos unidades narrati vas yuxtapuestas y finalmente enlazadas también pueden entenderse como sendas puestas en escena de concepciones opuestas acerca del acto de narrar y de leer. Ambas unidades aluden a los mismos sucesos, a la matanza de los Urquidi y a la cadena de venganzas implicadas en ella. Sín embargo, llaman también la atención los desplazamientos y las transformaciones que se producen de una narración a otra, pese a que ambas son-al menos formalmente-monodiálogos, que por lo demás pertenecen a una misma persona.

- Como es más o menos obvio, la última de estas narraciones se halla estructurada con base en los supuestos de la autoridad judicial, para quien la muerte del «hombre» no es de tomarse en consideración. Para dicha autoridad, no existe más «hecho» que la matanza de los Urquídi a manos del ahora occiso, y la sospecha de la complicidad del borreguero. Ambos supuestos llevan al narrador y declarante a bregar con dos imágenes estereotipadas y fijas: con la imagen moral y social que le adjudica su interlocutor, y con la de «asesino desalmado» que este mismo interlocutor asigna al «hombre.» Su papel consistirá entonces en desplazar el «hecho» pendiente de juzgar--de la matanza de los Urquidi hacia el asesinato del «hombre»-y en transformar la identidad moral de quienes se ven implicados tanto en la cadena de venganzas como en el relato de los hechos. Ambas operaciones se llevan a cabo mediante el entrecruzamiento de dos planos: mediante la adhesión fingida del narrador a la imagen que le impone su interlocutor acerca de sí mismo-la de «ignorante»y «crédulo»-y, amparado por dicha imagen, mediante el mantenimiento obstinado de su punto de vista acerca del «hombre.» Desde una perspectiva distanciada y externa-que, pese a la forma gramatical de la enunciación, equivale a la de un narrador en tercera persona-va sumando diversas escenas que describen el comportamiento del «hombre» $y$ reproducen indirectamente sus palabras, contrarrestando así cada uno de los «juicios» perentorios de su (supuesto) interlocutor. Aparentemente ingenuo y 
crédulo en su convicción acerca de la «verdad» de su personaje, se explaya en narracíones minuciosas, mientras espera la acusación de complicidad y encubrimiento que ha de brindarle la ocasión de encarar a su interlocutor y de colocar a éste ante sus propios prejuicios, tanto acerca del hecho por juzgar como de los actores involucrados. Así, pese a la forma monodialogal que restituye el carácter concreto del narrador y de su destinatario, esta segunda'narración funciona a la manera de un relato tradicional, en el cual el lector/receptor-también tradicional, por cuanto orienta su «lectura» hacia la evaluación y el enjuiciamiento de narrador y personaje-se halla figurado por el representante de la ley. Con todo, es de notar que no por tratarse de un relato tradicional, el lector queda menos expuesto al cuestionamiento de sus prejuicios.

En la primera unidad narrativa en cambio-y de nueva cuenta pese a la forma gramatical de la voz narrativa-el destinatario de la narración es el propio narrador, con lo cual éste invita al lector a hacerse uno con su propia perspectiva, esencialmente movediza y orientada hacia el descubrimiento eventual de una «verdad» recóndita e impredecible. Ahora bien, lo singular de la narración de Rulfo consiste en que, yendo detrás de las huellas de un «hombre» con el cual siente afinidad, el narrador termina descubriendo imaginariamente a otro, o mejor dicho a la «verdad íntima» de quien personifica uno de los aspectos del poder con el cual habrá de verse confrontado luego. Con todo, el desplazamiento-que en este caso no concierne al «hecho» por enjuidar sino al «hombre» por conocer-no acarrea un trastocamiento de los valores del narrador y borreguero. La compenetración imaginaria con el inconsciente del perseguidor tan sólo deja abierta la evaluación de los hechos que subyacen en una persecución que el narrador imaginó como una pugna despiadada e, incierta entre fuerzas emparentadas con la vida y la muerte. Sin embargo, a juzgar por su actitud posterior ante la autoridad judicial y por el desenmascaramiento último de la bajeza con que el perseguidor ultimó a su víctima, la relegación del juicio ético en aras de la verdad escondida en esta cadena de venganzas no impide que, llegado el momento, se ponga de manifiesto la opción del narrador y borreguero, y su sentido de la justicia. De modo que la perspectiva interna, la autonomía de personajes y voces respecto del narrador, la movilidad de la foealización, y el inacabamiento semántico del relato no entrañan una renuncia a toda perspectiva valorativa y ética.

Unidos por la cadena de venganzas a la cual aluden, lós dos monodiálagos-tan distintos entre sí-que componen el cuento de Rulfo constituyen sendas puestas en escena de un mismo narrador/personaje en circunstancias de enunciación distintas. Estas diferencias de circunstancia conllevan modificaciones sustanciales no sólo en la forma y el tono de las narraciones, sino también en la foealización de los hechos referidos y en la configuración de la imagen de los personajes. Los desplazamientos y las transformaciones de hechos, personas 
y perspectivas inherentes a las circunstancias de cada enunciación podrían llevar a la conclusión, algo simplista, de que los mismos hechos no se narran siempre de la misma manera, o de que hay varios modos de relatar lo mismo según el destinatario. Todo relato sería entonces relativo, es decir parcial y adaptado a la imagen o las expectativas del interlocutor, cuando no intencionalmente distorsionado. Nos parece sin embargo que, pese a su marcada heterogeneidad formal, «El hombre» no se queda en este relativismo simple, ni en la indiferencia ética que pudiera acarrear este relativismo.

Aun cuando cada uno de los relatos del cuento de Rulfo pudiera considerarse como una unidad autónoma, dotada de forma y significación propias, el caso es que son partes de un mismo cuento, y no simplemente yuxtapuestas o contrastadas como sendas maneras de relatar unos «mismos hechos.» Entre ellos se tejen nexos diversos y profundos, que van mucho más allá de los sucesos aludidos o de la identidad del sujeto de ambas narraciones. Estos nexos implican,desde luego, la complementaci6n y la reorganización parcial de la información proporcionada por cada uno de los relatos. Una y otra permiten precisar en retrospectiva la identidad del primer narrador y la índole de su monodiálogo, y apreciar además en su justa dimensi6n un desenlace que s610 cobra toda su fuerza a partir de la verdad íntima, imaginada y descubierta a raíz del rastreo primero de las huellas del «hombre.» En efecto, este primer monodiálogo, con la verdad que sacó a relucir, permite disociar la postura del borreguero de su imagen social y más o menos estereotipada: no sólo de la qué priva en el representante de la ley, sino también de la que pudiera estar actuando en el lector. La existencia previa de este primer monodiálogo contribuye a fundar el valor y el sentido de la justicia del borreguero-a quien el representante de la ley se apresta a convertir en un nuevo perseguido-no en su situación de subordinación social, sino en su búsqueda, incierta y desprejuiciada, de la verdad que encierra la persecución imaginariamente reconstituida. Destaca así-y no sin humor, dado el uso que el declarante hace de su propia imagen estereotipada-la estatura humana del borreguero, y subraya por contraste tanto la prepotencia y la arbitrariedad del representante de la ley como la vileza del asesino del «hombre.»

Por último, la yuxtaposici6n, contraposición y engarce de las poéticas respectivas de los dos monodiálogos llaman a una reflexión acerca de la configuración del objeto de la representación artística. Aun cuando, como aparece en el segundo relato, la fuerza de los «hechos» puede llegar a poner los prejuicios del receptor en entredicho, estos «hech.os» no son en realidad datos puros. Como lo recuerda el primer relato, son datos construidos y elaborados, detrás de los cuales se hallan los hombres que los cometieron y la búsqueda desprejuiciada de las complejísimas e inesperadas verdades íntimas que movieron a éstos. Pero, detrás de estos «hechos $»$ está también la perspectiva valorativa de quien los fue seleccionando, 
realzando y configurando. De tal suerte que, si bien es cierto que la verdad es siempre aproximada y parcial, ello no implica que sea, por ello, éticamente indiferente. Entre las múltiples formas de la persecución en torno a las cuales se organiza el cuento de Rulfo. consta también la búsqueda medular-sin duda imprevisible y a ratos riesgosa-de verdades a la medida del Hombre. En esta búsqueda se hallan comprometidos, juntos. narradores y lectores.

\section{Notas}

J La «oralidad» de los cuentos de Juan Rulfo constituye sin duda un importante punto de acuerdo para buena parte de la crítica. A este respecto, se pueden consultar, entre olros: Rama (1981), Rowe (1988), Jiménez de Báez (1990), Lienhardt (1990,1991 Y 1992), Rowe y Schelling (1991), Pacheco (1992) y FeU (coord. 1992).

Los estudios mencionados constituyen un marco ge.neral de referencia, $y$ no aluden sino muy excepcionaLmente al cuento que nos proponemos analizar aquí. Destacan la proveniencia ruralloral del lenguaje de los narradores y personajes-el hecho de narrar desde la cultura popular oral-pero salvo excepción Rowe (1988) y Lienhardt (1990), no destacan los conflictos que se derivan de la transposición de esta «oralidad» al plano de la escritura. Dan por sentada la continuidad de ambos lenguajes, e incluso suelen presuponer la primacía de la oralidad sobre la escritura. Nuestro punto de partida es distinto:- parte de-la primacía de la escritura y la tradición letrada, y de la dificultad de reencontrar $y$ dar cabida a los lenguajes orales y vivos que la tradición «literaria y «letrada» contribuye a opacar. ASÍ, entendemos la poética narrativa como el conjunto de soluciones artísticas que buscan dàr salida al mencionado conflicto.

2 Para la realización de este trabajo, nos hemos basado en la segunda edición revisada por el autor, Rulfo (1980, 9a. y 1987). Col. «Popular.» México: FCE. En adelante, se señalará al final de cada cita la página correspondiente a la mencionada edición.

3 Nos referimos aquí a la convención según la cual el narrador extradigético y en tercera persona se entiende como un pura función. A este respecto, ef Hamburger (1986). Para una reflexión de orden general en tomo la mencionada convención; ef Perus (1996), Pensamos que esta convención, vuelta abstracta en la narrativa europea debido a la pérdida de la memoria de sus orígenes hablados, constituye a menudo una dificultad particular para los narradores latinoamericanos, por cuanto entra en conflicto con el predominio de formas de comunicación basadas, no en la generalización de fonnas culturales escritas (que pennean incluso la comunicación hablada), sino en tradiciones que siguen siendo principalmente orales. En este caso, lo que nos interesa mostrar es cómo Rulfo echa mano de la mencionada convención para llevarla hacia otro lugar.

4 Hacemos referencia aquí a la distinción establecida por Genette (1972).

5 Acerca del monóLogo interior y las diferentes modalidades de focalización del relato en la subjetividad propia, el Beaujour (1980). Obviamente, Rulfo no acude aquí a esta tradición letrada, sino que reencuentra una práctica viva de elaboración de la experiencia, que conjuga la indagación de hechos, la imaginación y la deliberación interna. El «género discursivo» que corresponde a dicha práctica se halla sin duda más próximo a los lenguajes 
«vivos»-no canonizados-que a la tradición literaria examinada por Beaujour. Es, en este sentido, más «oral» que «letrado.»

${ }_{6}$ CI Françoise Perus. «Los silencios de Juan Rulfo.» (1997). En prensa.

${ }_{7}$ CI Françoise Perus. «Algunas consideraciones histórico-teóricas para el estudio del cuento.» (1987).

${ }^{8}$ El término «monodiálogo» ha sido acuñado por Rama (1981). Ha sido retomado también por Pacheco (1992). Ambos autores se refieren al monodiálogo como una forma discursiva en primera persona que conlleva la presencia de un interlocutor que, aunque silencioso, desempeña un papel activo en la forma del enunciado monodialógico. Como se puede apreciar aquí, el «monodiálogo» puede adquirir formas bastante distintas entre sí, y hace falta en cada caso vincularlo con los géneros discursivos y las poéticas en las cuales se apoya. En este último aspecto, las variaciones en la orientación del discurso-hacia su objeto propio, hacia la palabra «ajena» o hacia la palabra propia--resultan de primordial importancia para un análisis que no se quede en la clasificación o la descripción puramente estilísticas.

${ }_{9}$ CI Juan Rulfo. «Los desafíos de la creación.» (1992).

\section{Obras citadas}

Beaujour. Michel. 1980. Miroirs d'encre. Col. «Poétique» París: Editions du Seuil. Genette, Gérard. 1972. Figures l/l. Col. «Poétique» París: Editions du Seuil.

Hamburger, Käte. 1986. Logiquedes genres littéraires. Tr. del alemán Pierre Cadot, pref. Gérard Genette. Col. «Poétique.» París: Editions du Seuil.

Jíménez de Báez, IveUe. 1990. Juan Rulfo: del páramo a la esperanza (una lectura crítica de su obra). México: FCE.

Lienhardt, Martin. 1990, 1991 Y 1992. La voz y su huella. La Habana: Casa de las Américas. Hannover: Ediciones del Norte y Lima: Ediciones Horizonte.

Pacheco, Carlos. 1992. La comarca oral (La ficcionalización de la oralidad cultural en la narrativa latinoamericana contemporánea). Caracas: La Casa de Bello.

Perus, Françoise. 1996. «Cultura popular y enunciación novelesca (en tomo al problema del narrador).» Vol. LXII. Crítica cultural y teoría literaria latinoamericanas, Revista Iberoamericana 176-177. Julio-diCiembre: 925-938.

1997. (En prensa). «Los silencios de Juan Rulfo.» Revista Canadiense de Estudios Hispánicos. Número especial dedicado a Juan Rulfo.

- _ 1987. «Algunas consideraciones histórico-teóricas para el estudio del cuento.» Plural 189: junio. México.

Rama, Ángel. 1981. Transculturación narrativa en América Latina. México: Siglo XXI. Rowe, William. 1988. El Llano en llamas. Londres: Grant and Cutlerffhames Books.

y Vivian Schelling. 1991. Memory and ModernitylPopular Culture in Latin America. LondresiNueva York: Verso..

Rulfo, Juan. 1992. «Los desafíos de la creación.» Juan Rulfo. Toda la obra. Coord. Claude Fell. Madrid: Archivos. 
«vivos»-no canonizados-que a la tradición literaria examinada por Beaujour. Es, en este sentido, más «oral» que «letrado.»

6Cf Françoise Perus. «Los silencios de Juan Rulfo.» (1997). En prensa.

${ }_{7} C f$ Françoise Peros. «Algunas consideraciones histórico-teóricas para el estudio del cuento.» (1987).

s El término «monodiálogo» ha sido acuñado por Rama (1981). Ha sido retomado también por Pacheco (1992). Ambos autores se refieren al monodiálogo como una forma discursiva en primera persona que conlleva la presencia de un interlocutor que, aunque silencioso, desempeña un papel activo en la forma del enunciado monodíalógico. Como se puede apreciar aquí, el «monodílogo» puede adquirir formas bastante distintas entre sí, y hace falta en cada caso vincularlo con los géneros discursivos y las poéticas en las cuales se apoya. En este último aspecto, las variaciones en la orientación del díscurso---hacia su objeto propio, hacia la palabra «ajena» o hacia la palabra propia-resultan de primordial importancia para un análisis que no se quede en la clasificación o la descripción puramente estilísticas. .

${ }^{9}$ Cf Juan Rulfo. «Los desafíos de la creación.» (1992).

\section{Obras citadas}

Beaujour, Michel. 1980. Miroirs d'encre. Col. «Poétique » París: Editions du Seuil.

Genette, Gérard. 1972. Figures IlI. Col. «Poétique,» París: Editions du Seuil.

Hamburger, Kăte. 1986. Logiquedes genres litttraires. Tr. del alemán Pierre Cadot, pref. Gérard Genette. Col. «Poétique.» París: Editions du Seui!.

Jiménezde Báez, Ivette. 1990. Juan Rulfo: del páramo a la esperanza (una lectura crítica de su obra). México: FCE.

Lienhardt, Martin. 1990. 1991 Y 1992. La voz y su huella. La Habana: Casa de las Américas, Hannover: Ediciones del Norte y Lima: Ediciones Horizonte.

Pacheco. Carlos. 1992. La comarca oral (Laficcionalización de la oralidad cultural en la narrativa latinoamericana contemporánea). Caracas: La Casa de Bello.

Perus, Françoise. 1996. «Cultura popular y enunciación novelesca (en torno al problema del narrador).» Vol. LXII. Crítica cultural y teoría literaria latinoamericanas, Revista Iberoamericana 176-177. Julio-diciembre: 925-938.

- - O 1997. (En prensa). «Los silencioś de Juan Rulfo.» Revista Canadiense de Estudios Hispánicos. Número especial dedicado a Juan Rulfo.

1987. «Algunas consideraciones histórico-teóricas para el estudio del cuento.» Plural 189: junio. México.

Rama, Ángel. 1981. Transculturación narrativa en América Latina. México: Siglo XXI. Rowe. William. 1988. El llano en llamas. Londres: Grant and Cutlertrhames Books.

- - y Vivían Schelling. 1991. Memory and Modernity/Popular Culture in Latín Am. enea. LondreslNueva York: Verso..

Rulfo, Juan. 1992. «Los desafíos de la creación،»Juan Rulfo. Toda la obra. Coord. Claude Fell. Madrid: Archivos. 